\title{
Economic Brief
}

May 2015, EB15-05

\section{Discount Window Lending: Policy Trade-offs and the 1985 BoNY Computer Failure}

By Huberto M. Ennis and David A. Price

On November 21, 1985, the Bank of New York (BoNY) suffered a software failure that left it unable to redeliver securities it had received from other institutions as an intermediary. The result of the failure was that the bank sought and received $\mathbf{\$ 2 2 . 6}$ billion in discount window lending from the New York Fed, a record-setting amount. The episode presents a case study for considering when discount window lending and similar interventions are justified as a matter of efficiency, as well as the need for policymakers to take account of possible moral hazard that may lead to inadequate safeguards against failures - whether operational breakdowns or deficient financial strategies.

The discount window, the main mechanism through which a Federal Reserve Bank makes loans to depository institutions, is typically described as having a limited role in the financial system: by lending only against good collateral and only to solvent institutions, the discount window assists those institutions in meeting short-term needs for liquidity.

This idealized account of the discount window, rooted in the writings of the nineteenth-century British commentators Walter Bagehot and Henry Thornton, has not always described the purposes of the discount window in practice, however. In the early years of the Federal Reserve System, the discount window was the Fed's principal tool of monetary policy. More recently, the discount window has been used at times to rescue institutions experiencing financial distress. Such instances have included the use of the discount window to support the commercial-paper market in 1970 in connection with the bankruptcy of Penn Central Transportation Co. and the provision of $\$ 8$ billion in discount window loans in 1984 and 1985 to Continental Illinois National Bank and Trust Co. and its holding company. In a 1992 article, Anna Schwartz looked at data from 1985 to 1991 and found that institutions "with a high probability of insolvency" received discount window loans during that period "almost daily."

The use of the discount window to aid distressed institutions was also a feature of the 2007-08 financial crisis. The Fed initially sought to encourage discount window borrowing by lowering the spread between the discount rate and the target federal funds rate and by prevailing upon large banks to tap the window to reduce stigma. ${ }^{2}$ 
To further encourage borrowing, it created the Term Auction Facility (TAF), similar to the discount window, which relied on an auction process to increase the anonymity of the borrowing banks. In March 2009 , outstanding TAF loans reached a peak of $\$ 493$ billion. $^{3}$

When it comes to discount window credit, understanding the trade-offs faced by policymakers during the financial crisis is a difficult task, partly because the crisis was a multifaceted episode. There is another episode in Fed history, however, that seems to provide a cleaner case study for identifying and assessing some of those trade-offs.

In November 1985, events at the Bank of New York (BoNY), now part of BNY Mellon, set in motion another exceptional use of the discount window, one that has received little attention from economists. ${ }^{4}$ The conduct of the Fed in that episode, including what was the largest discount window loan in history up to that point, presents interesting and difficult questions concerning the principles that should govern discount window lending.

\section{The Disruption}

In 1985, BoNY was one of the four institutions responsible for clearing most Treasury securities trades for major Wall Street brokers. These transactions were carried out through an electronic securities transfer system operated by the Fed called Fedwire. Clearing agents such as BoNY received securities from a party to a transaction (the selling side) and then redelivered the securities to the counterparty (the buying side), all via Fedwire. The Fed operated the system on a delivery-versus-payment basis. In such a system, when a clearing agent receives securities from the selling side of a transaction, the system automatically debits funds from the agent's reserve account to pay the party delivering the securities; throughout the day, this process can result in the clearing agent accumulating reserve account overdrafts (known as daylight overdrafts). In normal conditions, these overdrafts are typically short-lived as the clearing agent is constantly receiving credits in its reserve account from redelivering the securities to the accounts of the buying side of the transactions.
Following a record-setting volume of transfers by BoNY on Wednesday, November 20, the New York Fed received what appeared to be a routine communication from the bank early the next morning stating that it was still finishing work from the previous day. Consequently, BoNY indicated, it would not be ready to process Thursday's transfers until later that morning. ${ }^{5}$

At around 11:30 a.m., the New York Fed learned that BoNY had a software problem. What the New York Fed still did not know, and would not learn until the afternoon, was that the problem in the recently installed software was preventing BoNY from redelivering securities. A flaw in the software caused it to fail when it processed 32,000 transactions, a volume it had reached the previous day. BoNY's database of accounts and transactions had been damaged, making recovery highly difficult. Normally, BoNY would use information in the database to direct the New York Fed where to send the securities that BoNY was receiving; because BoNY was unable to do so, it was not receiving any payments to offset the debits that the New York Fed was taking out of its account. ${ }^{6}$ As transactions flowed in for which BoNY could not make redelivery, the bank rapidly accumulated daylight overdrafts with the New York Fed, totaling more than $\$ 20$ billion by 2:15 p.m. BoNY indicated that it expected to be operational again between 6 p.m. and 7 p.m.

By 8:30 p.m., with BoNY finally processing a trickle of its clearing transactions, its overdraft was nearly $\$ 30$ billion. The New York Fed extended the business hours of Fedwire; the securities wire would remain open until 1:30 a.m. and the funds wire until 2:15 a.m. The New York Fed did so to give BoNY the opportunity to reduce its daylight overdraft-now "daylight" in name only-and its eventual discount window loan by raising money in the financial markets and by redelivering whatever securities it could. At the closing time of the funds wire, BoNY obtained a discount window loan of $\$ 22.6$ billion, 150 percent of the bank's assets and more than three times the size of the peak borrowing of Continental Illinois the previous year. (The loan was fully secured by the customers' Treasury securities in addition to the assets of 
the bank itself.) Because BoNY miscalculated its position when Fedwire closed at 2:15 a.m., its reserve account was overdrawn by a further $\$ 1$ billion, so the total credit it received from the New York Fed was $\$ 23.6$ billion.

On the following day, November 22, BoNY was still not fully operational and accumulated an additional overdraft of $\$ 2$ billion by 11 a.m. The New York Fed then stopped accepting securities transfers for BoNY's account for approximately an hour and a half. New York Fed President E. Gerald Corrigan would eventually testify before Congress that although the stoppage was not widely known until around an hour after it started, "the result was a backup in the willingness and ability of some other market participants to transfer securities among themselves." Later in the day, BoNY resolved its computer problems and repaid the New York Fed.

\section{Rationale for the Intervention}

Was the Fed's large discount window loan appropriate? Assuming that the rationale for the intervention rests on grounds of efficiency, it is helpful to begin by considering whether a market failure was involved.

Although the clearing problems at BoNY were the outcome of operational risk rather than financial risk, they have a parallel in the financial distress that triggered interventions to support institutions during the 2007-08 crisis. During that crisis, of course, the externality perceived by policymakers was that of systemic risk - that is, the failure of certain large institutions would result in harm to third parties and the system as a whole. An important part of the logic of the Fed's BoNY intervention was that an externality existed in the Treasury securities transfer system; in this view, if a problem in BoNY's system led to a disruption of payments, this too would have led to harm to third parties. In the words of then Fed Chair Paul Volcker shortly after the episode, if the Fed had not continued extending credit to BoNY, "other market participants would have found themselves short of cash, other banks and their customers presumably would have been forced into overdraft, and requests for discount window assistance and financial pressures would have appeared elsewhere." Moreover, if inaction by the Fed had forced BoNY to close its clearing operations, it could have had a severe effect "on markets and third parties, sowing confusion at the least, and at worst a chain reaction of losses." ${ }^{17}$

Assuming that externalities existed (a debatable assumption for reasons we will note later) and assuming parties cannot efficiently insure themselves or take other measures to mitigate the risk of harms from a clearing failure at BoNY, then there is a question of the socially optimal level of safety for BoNY's clearing system. If it is highly costly for BoNY to safeguard against all operational disruptions, then it may not be optimal to require BoNY to make its system perfectly reliable. Indeed, Volcker held that this was the situation. ("In the last analysis," he said, "no mechanical system can be entirely fail-safe and also be commercially viable.") In that case, an efficient framework may be for BoNY to make its systems imperfectly safe and, in principle, for the Fed to intervene to minimize the social costs of the disruptions that occur.

Once markets expect intervention, however, moral hazard comes into play. Here again, there is an obvious analogy to the financial crisis. By providing support to distressed institutions, policymakers sought to minimize the social costs of disruptions stemming from the crisis, but in doing so, they altered the ex ante incentives of institutions (and their creditors) when making decisions relevant to the likelihood of future disruptions. If institutions and their creditors expect to receive help whenever the institution becomes financially distressed, the institutions will tend to take a higher-than-optimal level of risk.

When an implicit Fed guarantee is present in the market for securities clearing, brokers who would otherwise take into account the expected cost of disruption - either by insisting on lower prices from less-reliable clearing agents or by contracting with another clearing agent-will not do so. ${ }^{8}$ Since clearing agents do not suffer the full consequences of their decisions with respect to operational risk (in terms of reactions from customers, etc.), they will not have an adequate incentive to reduce those operational disruptions through, for example, the use of 
backup sites, system testing, protection from hacking and malicious software, and rigorous hiring and training. In summary, the Fed backstop makes market participants relatively insensitive to risks and induces risk-taking above and beyond what could be considered socially optimal.

\section{Managing Moral Hazard}

Thus, if the Fed creates an expectation of rescue through the discount window-or in any other way - the Fed also must create an incentive for firms to build sufficient resiliency into their infrastructures.

One approach is to charge a penalty rate for this lending when it arises from an operational failure. Both Volcker and Corrigan expressed support for such a policy following the BoNY episode. ${ }^{9}$ Under the rules of the discount window at that time, the interest rate of 7.5 percent paid by BoNY was actually less than the prevailing federal funds rate. (BoNY did pay a penalty rate on its $\$ 1$ billion overdraft.) Today, as the result of a policy change in 2003, the Fed charges a penalty rate for discount window lending in general. If the penalty rate does not provide a sufficient incentive to avoid operational failures, the Fed could charge a higher penalty rate in such cases, although this could be seen as a departure from the general post-2003 practice of "no questions asked" regarding the reason for discount window loans.

An alternative approach is to regulate and supervise operational risk. The Fed does oversee operational risk management, ${ }^{10}$ and the Basel II regulatory framework introduced operational risk as a factor in capital regulation. ${ }^{11}$ But as in the case of financial risk-taking, well-aligned incentives coming from market discipline are likely to be more effective in bringing about appropriate risk management than regulation alone.

While the discussion in the previous section assumed an externality in the clearing system for Treasuries that justifies public intervention, the existence of such an externality is debatable. ${ }^{12}$ All participants in the clearing system, and in payment systems generally, have contractual relationships. In general, in such a setting, the conventional version of an externality is unlikely to be present-that is, the situation in which one economic agent is subjected involuntarily to the effects of conduct by another party. While it is true that shareholders and creditors of a financial firm could bear losses if the firm experiences a permanent or even temporary failure to settle a transaction, this is not essentially different from the situation of, for example, shareholders and creditors of an automaker that has experienced a delivery failure of contracted-for parts.

If there is no externality, then we are just left with the moral hazard of market participants and the time inconsistency of policy interventions. That is, when an operational failure happens, the central bank perceives that some participants will experience a significant disruption of services and regards the associated (ex post) costs as inefficient. The reaction of policymakers may be to dedicate resources to minimize those loses. But with the expectation of such a rescue, participants in the payments system may economize on the cost of avoiding failures and hence allow some of those failures to happen more often.

The fact that a computer software failure takes place does not mean that the situation was inefficient ex ante. Private parties make decisions ex ante that optimally balance the costs and expected benefits of measures to render the system safer. This is reasonably intuitive in the case of a software failure.

In fact, this logic applies more generally. Illiquidity and financial distress can be the result of an ex ante optimal economic decision. Holding large liquidity buffers often involves a trade-off by taking away resources from productive activities that may involve some degree of illiquidity. The idea that some financial arrangements should be allowed to involve a certain level of liquidity risk deserves serious consideration. But, just as with software failures, the realization of those risks does not justify intervention by itself.

When an externality gives rise to a good reason to intervene, moral hazard is an issue that policymakers must manage. In those cases, penalties (such as the penalty rate at the discount window) 
and supervision should complement the intervention. When there are no externalities, however, there is no reason for intervening based on efficiency considerations, yet there may still be an ex post temptation to intervene. If market participants anticipate such intervention, the result is moral hazard and the associated inefficiency. In that case, failures may occur more often than the efficient rate because underinvestment in safety transfers resources to payments system participants from outside the payments system.

Huberto M. Ennis is a senior economist and research advisor and David A. Price is senior editor in the Research Department at the Federal Reserve Bank of Richmond.

\section{Endnotes}

1 See Schwartz, Anna J., "The Misuse of the Fed's Discount Window," Federal Reserve Bank of St. Louis Review, September/ October 1992, vol. 74, no. 5, pp. 58-69. See also Committee on Banking, Finance and Urban Affairs, U.S. House of Representatives, "An Analysis of Federal Reserve Discount Window Loans to Failed Institutions," June 11, 1991.

2 See, for example, Berger, Allen N., Lamont K. Black, Christa H.S. Bouwman, and Jennifer Dlugosz, "The Federal Reserve's Discount Window and TAF Programs: 'Pushing on a String?"' Manuscript, October 2014, p. 14, n. 29.

3 See Courtois, Renee, and Huberto M. Ennis, "Is There Stigma Associated with Discount Window Borrowing?" Federal Reserve Bank of Richmond Economic Brief, May 2010. See also Price, David A., "When the Fed Conducts Credit Policy," Federal Reserve Bank of Richmond Region Focus, First Quarter 2012, pp. 6-8.

${ }^{4}$ An exception is Lacker, Jeffrey M., "Payment System Disruptions and the Federal Reserve Following September 11, 2001," Federal Reserve Bank of Richmond Working Paper No. 03-16, December 23, 2003, pp. 21-22.

${ }^{5}$ This account is based on the subsequent testimony of E. Gerald Corrigan, then-president of the New York Fed; on the testimony of J. Carter Bacot, then-chairman and chief executive officer of BoNY; and on contemporaneous articles in the Wall Street Journal and American Banker. See "Statement of E. Gerald Corrigan," Hearing before the Subcommittee on Domestic Monetary Policy of the Committee on Banking, Finance and Urban Affairs, U.S. House of Representatives, December 12, 1985, pp. 23-30 (hereinafter "Hearing"); "Statement of J. Carter Bacot," Hearing, pp. 84-88.
${ }^{6}$ BoNY was receiving securities from the selling side of the transactions, but was not able to redirect the securities to the buying side of the transactions. In effect, BoNY's balance sheet was growing with each transaction during the day as it accumulated securities on the asset side and daylight credit from the New York Fed on the liability side.

7 Hearing, p. 7.

${ }^{8}$ Relatedly, research by the New York Fed suggests that settlement fails by broker-dealers are often related to their incentives or lack of incentives to avoid failures. See Fleming, Michael J., and Kenneth D. Garbade, "Explaining Settlement Fails," Federal Reserve Bank of New York Current Issues in Economics and Finance, September 2005, vol. 11, no. 9.

9 Hearing, pp. 7, 26.

10 See Federal Reserve Board of Governors, "Supervisory Policy and Guidance Topics: Operational Risk Management," www. federalreserve.gov/bankinforeg/topics/op_risk_mgmt.htm.

11 See Basel Committee on Banking Supervision, "International Convergence of Capital Measurement and Capital Standards: A Revised Framework," June 2004, pp. 137-149.

12 See Lacker, Jeffrey M., "Payment Economics and the Role of Central Banks," in Haldane, Andrew G., et al., eds., The Future of Payment Systems, New York: Routledge, 2008, pp. 68-72.

This article may be photocopied or reprinted in its entirety. Please credit the authors, source, and the Federal Reserve Bank of Richmond and include the italicized statement below.

Views expressed in this article are those of the authors and not necessarily those of the Federal Reserve Bank of Richmond or the Federal Reserve System.

\section{FEDERAL RESERVE BANK OF RICHMOND}

